\section{Organic Mulch and Nitrogen Affect Spring and Fall Collard Yields}

\author{
E.A. Guertal ${ }^{1}$ \\ Department of Agronomy and Soils, Auburn University, Auburn, AL 36849
}

J.H. Edwards ${ }^{2}$

U.S. Department of Agriculture, Agricultural Research Service, National Soil Dynamics Laboratory, Auburn, AL 36849

Additional index words. Brassica oleracea, fertilizer, vegetable nutrition

\begin{abstract}
Fall and spring collards (Brassica oleracea L. Acephala Group) were grown under one of three mulches (black plastic, ground newspaper, wood chips) and in a bare soil control. Mulch treatments were arranged in a factorial design with five rates of $\mathbf{N}$ fertilizer: $0,67,134,201$, or $268 \mathrm{~kg} \mathrm{~N} / \mathrm{ha}$. All fertilizer was preplant-incorporated into the bed before applying mulches and transplanting collards. Season did not affect collard yield, and there was no significant season $\times N$ rate interaction. Collard yields increased with increasing rates of $\mathrm{N}$, with a maximum yield at $163 \mathrm{~kg} \mathrm{~N} / \mathrm{ha}$. Mulch type significantly affected collard yield, with fall collard yields highest under bare ground or wood chip mulches and spring yields highest under black plastic mulch. Collards produced under newspaper mulch produced the lowest yields in the fall and yields equal to bare soil and wood chips in the spring. Collards produced under newspaper mulch had less tissue $\mathrm{N}$ at harvest than those of any of the other treatments in both seasons. Collards produced on black plastic produced the lowest plant populations in both seasons. Wood chips and newspaper offer some appeal as low-input, small-scale mulches, but additional research to explore fertility management is necessary.
\end{abstract}

Municipal solid waste (MSW) represents one of the largest contributions to our nation's landfills. Consisting of items such as newspaper, grass clippings, and yard trimmings, MSW comprises $\approx 65 \%$ of landfill volume (Edwards et al., 1995). Using MSW in agricultural cropping systems may offer an alternative to costly and wasteful landfill disposal. Use of MSW as a mulch in vegetable production systems may provide a low-input alternative to polyethylene mulches or an improvement over bareground production systems for small-scale or home garden use. Previous examinations of MSW as a soil amendment did not include $\mathrm{N}$ rates, or $\mathrm{N}$ was added to adjust the $\mathrm{C}: \mathrm{N}$ ratio of MSW to 30:1 (Carter and Johnson, 1988; Edwards et al., 1994). To our knowledge, no data are available on the relationship between fertilizer rates and organic mulches and crop yield. The objective of this experiment was to determine the effect of several mulches and $\mathrm{N}$ rates on yield and tissue $\mathrm{N}$ of fall and spring collards.

\section{Materials and Methods}

A field study was initiated in Fall 1993 at the Sand Mountain Substation near Crossville,

Received for publication 10 Oct. 1995. Accepted for publication 15 Mar. 1996. The cost of publishing this paper was defrayed in part by the payment of page charges. Under postal regulations, this paper therefore must be hereby marked advertisement solely to indicate this fact.

${ }^{1}$ Assistant Professor, Agronomy and Soils.

${ }^{2}$ Adjunct Associate Professor, Agronomy and Soils.
Ala. (lat. $34^{\circ} 18^{\prime} \mathrm{N}$, long. $86^{\circ} 01^{\prime} \mathrm{W}$ ). Before 1993, the study site had been fallow and planted to winter rye for 3 years. Soil type was a Hartsell fine sandy loam (fine-loamy, siliceous, thermic Typic Hapludult). Initial soil tests using the Mehlich-1 extract indicated average $\mathrm{P}, \mathrm{K}, \mathrm{Mg}$, and $\mathrm{Ca}$ concentrations of 27, 100, 117, and $465 \mathrm{mg} \cdot \mathrm{kg}^{-1}$, a "high" soil test rating for $\mathrm{P}, \mathrm{K}$, and $\mathrm{Mg}$ (Adams et al., 1994). Average soil $\mathrm{pH}$ was 6.2. The experiment consisted of five $\mathrm{N}$ rates and four mulches (20 treatments) arranged in a randomized comeach treatment.

Each plot consisted of a single $15-\mathrm{cm}$ raised planting bed $76 \mathrm{~cm}$ wide and $3 \mathrm{~m}$ long. Eightweek-old 'Champion' collard plants were hand-transplanted in double rows with a 30$\mathrm{cm}$ within- and between-row spacing for a population of 28,700 plants/ha. Fall collard plants were transplanted 9 Sept. 1993 and spring collards were transplanted 16 Mar. 1994, after application of fertilizer and mulch treatments for that crop. Nitrogen was applied as $\mathrm{NH}_{4} \mathrm{NO}_{3}(34 \mathrm{~N}-0 \mathrm{P}-0 \mathrm{~K})$ at $0,67,134,201$, or $268 \mathrm{~kg} \mathrm{~N} / \mathrm{ha}$. Phosphate and potash were applied to all plots at $43 \mathrm{~kg} \mathrm{P} / \mathrm{ha}$ and $39 \mathrm{~kg} \mathrm{~K} / \mathrm{ha}$ as triple superphosphate $(0 \mathrm{~N}-45 \mathrm{P}-0 \mathrm{~K})$ and $\mathrm{KCl}(0 \mathrm{~N}-0 \mathrm{P}-62 \mathrm{~K})$, respectively, as recommended by the Auburn Univ. Soil Testing Laboratory (Adams et al., 1994). Fertilizers were broadcast and lightly irrigated into each planting bed before application of mulch materials.

After application of fertilizer and before transplanting, mulches were applied to each plot: 1) none (bare soil); 2) black plastic polyethylene mulch; 3) wood chips [50 C : $1 \mathrm{~N}$ $(0.96 \%$ total $\mathrm{N})]$; and 4$)$ ground newspaper plete-block design with four replications of
[100 C : $1 \mathrm{~N}(1.2 \%$ total N)]. Black plastic was laid by hand, simulating application with a commercial bedding machine. Newspaper and wood chips were applied at $24,000 \mathrm{~kg}$ dry material/ha, corrected for moisture content by oven-drying subsamples of wood chips and newspaper. Newspaper was applied as a ground material, with an average particle size of $\approx 0.1$ $\mathrm{cm}^{2}$. Wood chips had an average particle size of $\approx 1.6 \mathrm{~cm}^{2}$. Because mulches were applied on a weight basis, volumes of material covering the planting bed varied, with the wood chips and newspaper forming layers $\approx 1.3$ and $7.6 \mathrm{~cm}$ deep, respectively. Total $\mathrm{P}, \mathrm{K}, \mathrm{Ca}$, and $\mathrm{Mg}$ concentrations as determined via inductively coupled argon plasma spectroscopy (ICAP) (Hue and Evans, 1986) were 1900, 5000, 5400, and $1900 \mathrm{mg} \cdot \mathrm{kg}^{-1}$ in wood chips and 40, 90, 1300 , and $100 \mathrm{mg} \cdot \mathrm{kg}^{-1}$ in newspaper (dryweight basis), respectively. Wood chips were 9.9\% ash and newspaper $3.3 \%$.

Once mulches had been applied, plots were irrigated lightly to moisten the mulches and prevent movement. Throughout the study, irrigation was applied via overhead solid-set sprinklers to maintain soil tension at 20 to 25 $\mathrm{kPa}$. Because solid-set sprinklers prevented separate irrigation of mulch treatments, tensionmeters were placed in each bare soil plot at a depth of $30 \mathrm{~cm}$.

Weed control included a preplant-incorporated application of $\alpha, \alpha, \alpha$-trifluoro-2,6dinitro- $N, N$-dipropyl- $p$-toluidine (trifluralin) at $0.6 \mathrm{~kg}$ a.i./ha, before mulch application and transplanting of the fall crop. Insecticide consisted of 1-naphthyl $N$-methylcarbamate (carbaryl) at $1.2 \mathrm{~kg}$ a.i./ha, applied every 10 days to within 14 days of harvest. Planting beds were not reformed after the harvest of the fall crop, and the spring crop was transplanted into existing beds that were kept free of weeds with applications of $N$-(phosphonomethyl) glycine (glyphosate) as needed. All mulches were removed by hand after the fall harvest. Nitrogen fertilizer was surface-applied and lightly irrigated for the spring crop, with new mulches applied immediately thereafter.

Fall and spring collard crops were harvested at the 23-leaf stage on 3 Dec. 1993 and 15 June 1994, after 80 and 90 days of growth, respectively. Plants at either end of the plot were not harvested, eliminating differential growth due to plot-edge effects. Total harvested plot length was $2.7 \mathrm{~m}$. Number of plants in each plot was recorded, providing a measure of plant survival. Total fresh weight of harvested plants was determined, and a subsample of whole plants was dried for total $\mathrm{N}$ analysis of plant tissue. The most recent and fully emerged leaves were sampled from the fall collard crop at the eight-leaf growth stage and were dried and ground for total $\mathrm{N}$ analysis via dry combustion techniques (Keeney and Nelson, 1982).

Immediately following each harvest, soil samples were taken from each plot to a depth of $15 \mathrm{~cm}$. Samples were air-dried (20C), ground to $<0.6 \mathrm{~mm}$, and analyzed for soil $\mathrm{NO}_{3}-\mathrm{N}$ and $\mathrm{NH}_{4}-\mathrm{N}$ in $2 \mathrm{M} \mathrm{KCl}$ extracts using automated colorimetric techniques (Keeney and Nelson, 1982). 


\section{Results and Discussion}

Collard yield. Because there was no significant harvest $\times \mathrm{N}$ rate interaction $(P=$ 0.228 ) and standard errors indicated that mean yields did not significantly differ due to harvest, one regression equation was used to describe collard yield for both harvests (Fig. 1). Collard yields increased with increasing rates of $\mathrm{N}$, with a maximum yield at $163 \mathrm{~kg} \mathrm{~N} /$ ha. Biomass yields were similar to those found in previous Alabama research (Dangler and Wood, 1993) that was conducted with a comparable open-pollinated variety ('Vates') and similar rates of $\mathrm{N}$ fertilization.

There was no significant $\mathrm{N}$ rate $\times$ mulch interaction present in either collard harvest, although main effects of mulch and $\mathrm{N}$ rate were significant in both harvests. Collard yield as a function of mulch type varied by season. In the fall, there was no significant difference between the high-yielding treatments of wood chips and bare soil (Table 1). Newspaper was the lowest yielding treatment, $26 \%$ lower than for wood chips or bare soil and $13 \%$ lower than for black plastic. In the spring, collards grown under black plastic produced yields that were $51 \%$ higher than with any other mulch, although plant populations were lower.

Seasonal or yearly differences in crop yields because of mulch have been observed in other studies. Black plastic mulch significantly increased eggplant (Solanum melongena $\mathrm{L}$.) yield when compared to newspaper mulch, pine needle mulch, or a bare soil control in the first year of a study, but black plastic and pine needles significantly increased yields over newspaper and bare soil in year 2 of the study. Black plastic and pine needles were more effective than newspaper in conserving moisture and controlling weeds (Carter and Johnson, 1988).

Plant population. Fall plant populations were $32 \%$ higher in the wood chip mulch and bare soil than in newspaper mulch (Table 1). Although populations of spring collards under black plastic were lowest, yields were highest, indicating that individual plants were larger in that treatment. Increased plant size may have been the result of warmer soils from the black plastic mulch or conservation of soil moisture, but temperature or soil moisture readings are not available to confirm this hypothesis.

Tissue N samples. Percent $\mathrm{N}$ determined at the fall eight-leaf growth stage and wholeplant $\mathrm{N}$ determined at spring harvest were significantly affected by main effects of mulch and $\mathrm{N}$ rate (Table 2). Percent $\mathrm{N}$ in collards sampled at the fall eight-leaf stage increased significantly and linearly from an average of $3.76 \%$ in the control $(0 \mathrm{~N})$ to $5.42 \%$ at the highest $\mathrm{N}$ rate $(268 \mathrm{~kg} \mathrm{~N} / \mathrm{ha})$. When examined as a function of mulch treatment, eight-leaf stage collards grown under black plastic contained $0.43 \%$ more $\mathrm{N}$ than collards of any other treatment. Collard leaf samples from other mulch treatments did not differ in $\mathrm{N}$ content, with a mean concentration of $4.73 \% \mathrm{~N}$.

Whole-plant samples from the spring harvest also increased in percent $\mathrm{N}$ as $\mathrm{N}$ rate increased, with collards from the highest rate

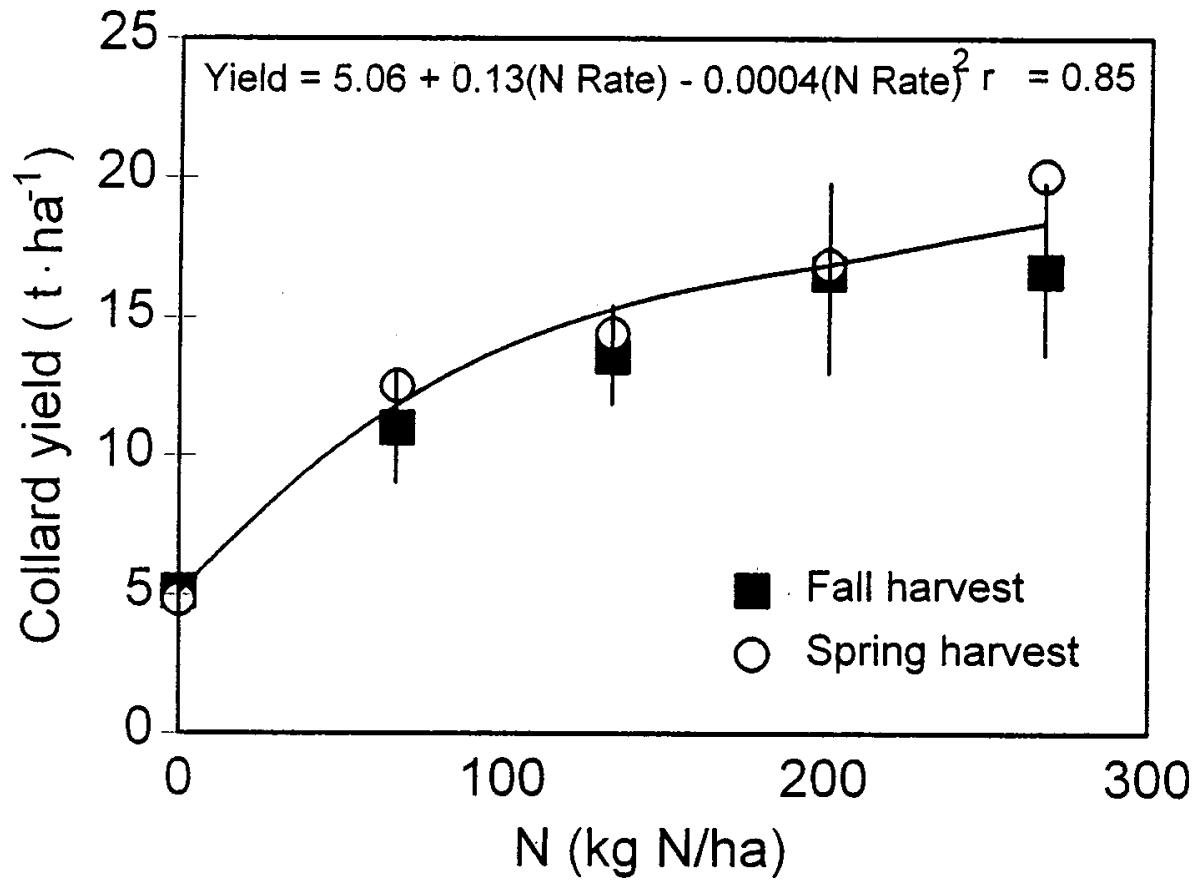

Fig. 1. Spring and fall collard yields as affected by N fertilization, 1993-94.

Table 1. Collard yield and plant population as affected by mulch treatment, 1993-94.

\begin{tabular}{lccccc}
\hline \hline & \multicolumn{2}{c}{$\begin{array}{c}\text { Yield } \\
\left(\mathrm{t} \cdot \mathrm{ha}^{-1}\right)\end{array}$} & & \multicolumn{2}{c}{$\begin{array}{c}\text { Plant population } \\
\text { [plants/ha (1000s)] }\end{array}$} \\
\cline { 2 - 3 } \cline { 5 - 6 } Mulch & Fall harvest & Spring harvest & & Fall harvest & Spring harvest \\
\hline Bare soil & $13.5 \mathrm{a}^{2}$ & $13.2 \mathrm{~b}$ & & $21.4 \mathrm{a}$ & $20.7 \mathrm{~b}$ \\
Black plastic & $12.0 \mathrm{~b}$ & $18.4 \mathrm{a}$ & & $16.4 \mathrm{c}$ & $17.1 \mathrm{c}$ \\
Wood chips & $14.7 \mathrm{a}$ & $13.0 \mathrm{~b}$ & & $22.0 \mathrm{a}$ & $23.2 \mathrm{a}$ \\
Newspaper & $10.4 \mathrm{c}$ & $10.5 \mathrm{~b}$ & & $19.8 \mathrm{~b}$ & $22.4 \mathrm{ab}$ \\
\hline
\end{tabular}

${ }^{\mathrm{z}}$ For each harvest, mean separation by Duncan's multiple range test at $P<0.05$.

Table 2. Analysis of variance of total N in collard whole-plant and fall leaf samples, 1993-94.

\begin{tabular}{lccc}
\hline Source & $\mathrm{df}$ & $\mathrm{SS}$ & $P>\mathrm{F}$ \\
\hline & Eight-leaf stage_Fall & & \\
N rate & 4 & 31.4 & 0.0001 \\
$\quad$ Linear & 1 & 27.0 & 0.0001 \\
$\quad$ Quadratic & 1 & 4.5 & 0.0004 \\
Mulch & 3 & 3.4 & 0.019 \\
N rate $\times$ mulch & 12 & 5.0 & 0.227 \\
& & & \\
N rate & 4 & Fall harvest & 0.0001 \\
$\quad$ Linear & 1 & 41.2 & 0.0001 \\
Quadratic & 1 & 0.02 & 0.733 \\
Mulch & 3 & 10.5 & 0.0001 \\
N rate $\times$ mulch & 12 & 5.3 & 0.003 \\
& & & \\
N rate & 4 & 10.3 & 0.0002 \\
$\quad$ Linear & 1 & 8.4 & 0.0001 \\
$\quad$ Quadratic & 1 & 1.8 & 0.039 \\
Mulch & 3 & 5.6 & 0.005 \\
N rate $\times$ mulch & 12 & 4.2 & 0.567 \\
\hline
\end{tabular}

(268 kg N/ha) containing $0.81 \%$ more $\mathrm{N}$ than those from any other $\mathrm{N}$ treatment. There was no difference in $\mathrm{N}$ concentration of collards grown under plastic $(3.25 \% \mathrm{~N})$, wood chips $(3.11 \% \mathrm{~N})$, or bare soil $(2.95 \% \mathrm{~N})$, although the $\mathrm{N}$ concentration of spring collards grown under newspaper was $0.57 \%$ less.

A significant mulch $\times \mathrm{N}$ rate interaction occurred with whole-plant $\mathrm{N}$ in the fall harvest (Table 2 and Fig. 2). The interaction was partitioned using single-degree-of-freedom contrasts, which revealed that any contrast that included plastic mulch was significant $(P$ $<0.0001)$ and those without plastic were nonsignificant. Collards grown under black plastic contained $0.78 \%$ more $\mathrm{N}$ than those from bare soil, wood chips, or newspaper, which had a mean concentration of $3.07 \%$. Nitrogen rate greatly affected $\mathrm{N}$ concentration, as each increase in $\mathrm{N}$ applied significantly increased percent $\mathrm{N}$ in collards over the previous treatment. Nitrogen concentration of fall-harvested 
collards ranged from $2.29 \%$ in the control $(0$ N) to $4.27 \%$ at $268 \mathrm{~kg} \mathrm{~N} / \mathrm{ha}$.

Differences in plant $\mathrm{N}$ at harvest were perhaps a function of decreased available soil $\mathrm{N}$, as mulches with high $\mathrm{C}: \mathrm{N}$ ratios may have immobilized $\mathrm{N}$ at the soil-mulch interface. Percent $N$ in collards in fall and spring harvests was lowest with newspaper or wood chip mulch-materials with high $\mathrm{C}: \mathrm{N}$ ratios (>50:1). Roe et al. (1994) found no difference in leaf $\mathrm{N}$ in peppers (Capsicum annuum var. annиит $\mathrm{L}$.) due to surface-applied composted organic mulches (municipal solid waste compost and sewage sludge-yard trimming compost), suggesting that immobilization of $\mathrm{N}$ was not apparent. However, such composted materials may have $\mathrm{C}: \mathrm{N}$ ratios that are closer to 20:1, a function of the stability and maturity of the composted material (Jimenez and Garcia, 1989).

Soil $\mathrm{NO}_{3}-\mathrm{N}$ and $\mathrm{NH}_{4}-\mathrm{N}$. In the fall, soil $\mathrm{NO}_{3}-\mathrm{N}$, but not soil $\mathrm{NH}_{4}-\mathrm{N}$, was significantly affected by $\mathrm{N}$ rate and mulch $(P<0.05)$ (Table $3)$. Further study of the significant $\mathrm{N}$ rate $\times$ mulch interaction for fall soil $\mathrm{NO}_{3}-\mathrm{N}$ (Fig. 3) revealed that there was significantly more $\mathrm{NO}_{3}$ $\mathrm{N}$ in samples from the highest $\mathrm{N}$ rate $(268$ $\mathrm{kg} \cdot \mathrm{ha}^{-1}$ ) than from any other treatment. There was no difference in soil $\mathrm{NO}_{3}-\mathrm{N}$ in any remaining treatments (average of $1.23 \mathrm{mg} \cdot \mathrm{kg}^{-1}$ ). There was $74 \%$ more soil $\mathrm{NO}_{3}-\mathrm{N}$ under black plastic mulch than in any other plot; the others had a mean soil $\mathrm{NO}_{3}-\mathrm{N}$ concentration of 1.44 $\mathrm{mg} \cdot \mathrm{kg}^{-1}$. This increase in soil $\mathrm{NO}_{3}-\mathrm{N}$ may be a combined factor of increased mineralization from warmer soil under black plastic and reduced immobilization of $\mathrm{N}$ as compared to mulch treatments with high $\mathrm{C}: \mathrm{N}$ ratios (newspaper, wood chips).

In the spring, only the main effect of $\mathrm{N}$ rate for soil $\mathrm{NO}_{3}-\mathrm{N}$ was significant (Table 3), with significantly more soil $\mathrm{NO}_{3}-\mathrm{N}$ present $(5.67$ $\left.\mathrm{mg} \cdot \mathrm{kg}^{-1}\right)$ at the highest $\mathrm{N}$ rate than for the $0 \mathrm{~N}$ control (4.30 mg. $\left.\mathrm{kg}^{-1}\right)$. Neither mulch nor $\mathrm{N}$ rate affected soil $\mathrm{NH}_{4}-\mathrm{N}$ concentration, with an average concentration of $0.44 \mathrm{mg} \cdot \mathrm{kg}^{-1}$.

The use of alternative mulches, such as wood chips or newspaper, may be possible in low-input vegetable production systems that rely on hand labor. Hand-applied ground newspaper and wood chips stayed in place throughout the growing season, and the newspaper provided excellent weed control. The newspaper was easy to remove in preparation for the next growing season, while the wood chips were slightly more difficult to rake from each plot. Soil incorporation of the wood chips and newspaper would present a new set of questions, as yearly incorporation of such materials would affect soil chemistry.

Possible immobilization of $\mathrm{N}$ may be offset by frequent application of $\mathrm{N}$ through a drip irrigation system. Research that has used drip systems in conjunction with organic mulches did not involve a change in rate of $\mathrm{N}$, and the organic mulches in those systems contained higher nutrient concentrations than concentrations found in unprocessed newspaper or wood chips (Roe et al., 1994). Newspaper offers an environmentally friendly mulch, but additional research that explores rates of newspaper ad-



Fig. 2. Total N in collard whole-plant samples as affected by mulch and N rate, Fall 1993, dry-weight basis.

Table 3. Analysis of variance of soil $\mathrm{N}$ as affected by N rate and mulch, 1993-94.

\begin{tabular}{|c|c|c|c|}
\hline Source & df & SS & $P>\mathrm{F}$ \\
\hline \multicolumn{4}{|c|}{ Fall soil $\mathrm{NO}_{3}-\mathrm{N}$} \\
\hline $\mathrm{N}$ rate & 4 & 31.1 & 0.0002 \\
\hline Linear & 1 & 20.2 & 0.0001 \\
\hline Quadratic & 1 & 9.4 & 0.003 \\
\hline Mulch & 3 & 10.5 & 0.02 \\
\hline $\mathrm{N}$ rate $\times$ mulch & 12 & 28.8 & 0.019 \\
\hline \multicolumn{4}{|c|}{ Fall soil $\mathrm{NH}_{4}-\mathrm{N}$} \\
\hline $\mathrm{N}$ rate & 4 & 3.5 & 0.058 \\
\hline Linear & 1 & 1.4 & 0.048 \\
\hline Quadratic & 1 & 0.4 & 0.258 \\
\hline Mulch & 3 & 2.6 & 0.067 \\
\hline $\mathrm{N}$ rate $\times$ mulch & 12 & 5.5 & 0.224 \\
\hline \multicolumn{4}{|c|}{ Spring soil $\mathrm{NO}_{3}-\mathrm{N}$} \\
\hline $\mathrm{N}$ rate & 4 & 17.0 & 0.015 \\
\hline Linear & 1 & 16.7 & 0.0006 \\
\hline Quadratic & 1 & 0.1 & 0.816 \\
\hline Mulch & 3 & 4.7 & 0.318 \\
\hline $\mathrm{N}$ rate $\times$ mulch & 12 & 7.9 & 0.893 \\
\hline \multicolumn{4}{|c|}{ Spring soil $\mathrm{NH}_{4}-\mathrm{N}$} \\
\hline $\mathrm{N}$ rate & 4 & 1.0 & 0.312 \\
\hline Linear & 1 & 0.6 & 0.102 \\
\hline Quadratic & 1 & 0.01 & 0.918 \\
\hline Mulch & 3 & 0.5 & 0.469 \\
\hline $\mathrm{N}$ rate $\times$ mulch & 12 & 2.4 & 0.483 \\
\hline
\end{tabular}

dition to optimize yield is needed. Wood chips produced collards with excellent plant stands and competitive yields, but long-term incorporation of a mulch with such a high $\mathrm{C}: \mathrm{N}$ ratio may pose fertility management problems.

\section{Literature Cited}

Adams, J.F., C.C. Mitchell, and H.H. Bryant. 1994. Soil test fertilizer recommendations for Alabama Crops. Agron. \& Soils Dept. Ser. 178. Alabama Agr. Expt. Sta., Auburn Univ.

Carter, J. and C. Johnson. 1988. Influence of different types of mulches on eggplant production. HortScience 23:143-145.

Dangler, J.M. and C.W. Wood. 1993. Nitrogen rate, cultivar and within-row spacing affect collard yield and leaf nutrient concentration. HortScience 28:701-703

Edwards, J.H., E.C. Burt, R.L. Raper, and R.H Walker. 1995. Issues affecting application of noncomposted organic waste to agricultural land, p. 225-250. In: Agricultural utilization of urban and industrial by-products. Soil Sci. Soc. Amer. Spec. Publ. 59.

Edwards, J.H., R.H. Walker, E.A. Guertal, L.D Norton, and J.T. Eason. 1994. Options for recycling organics on farm land. BioCycle 35:6668.

Hue, N.V. and C.E. Evans. 1986. Procedures used for soil and plant analysis by the Auburn University Soil Testing Laboratory. Agron. \& Soils 


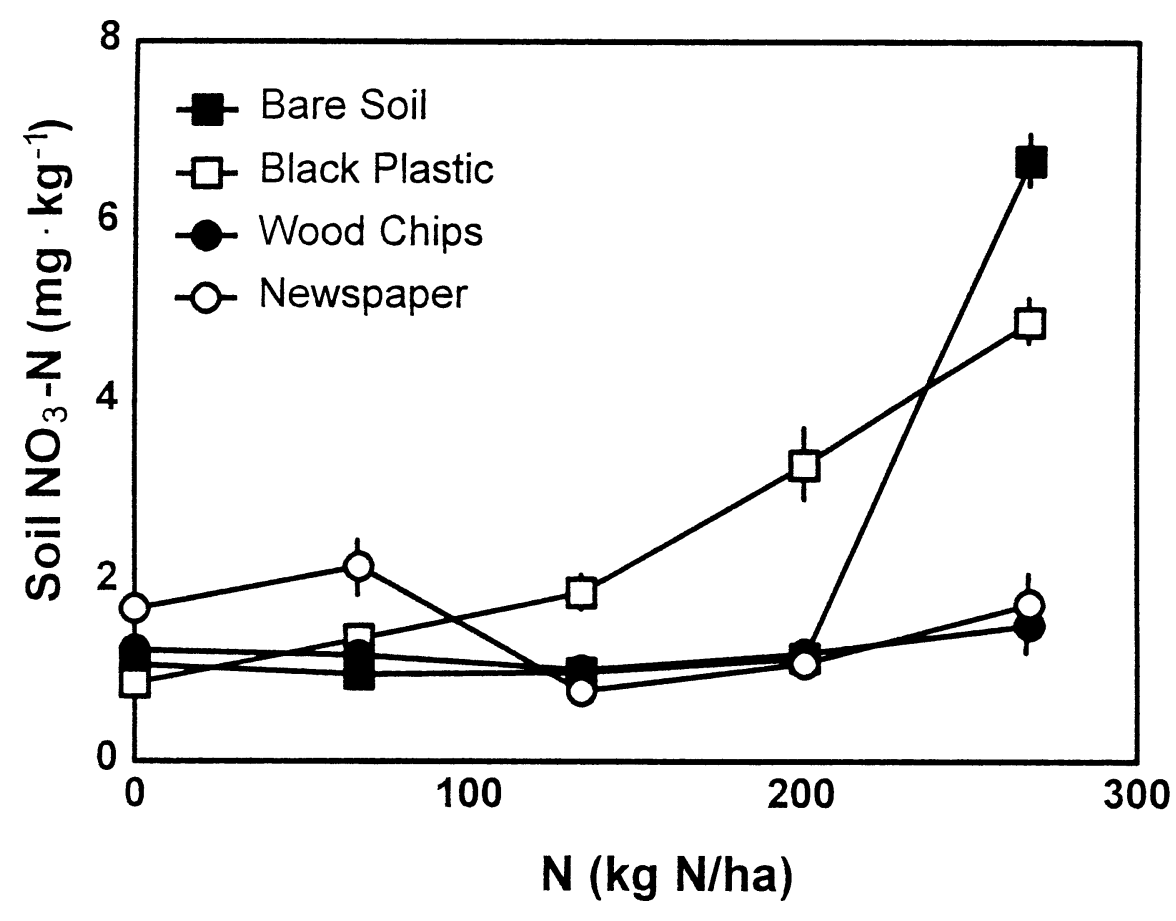

Fig. 3. Soil $\mathrm{NO}_{3}-\mathrm{N}$ as affected by mulch and $\mathrm{N}$ rate, Fall 1993.
Dept. Ser. 106. Alabama Agr. Expt. Sta., Auburn Univ.

Jimenez, E.I. and V.P. Garcia. 1989. Evaluation of city refuse compost maturity: A review. Biol. Wastes 27:115-142.

Keeney, D.R. and D.W. Nelson. 1982. NitrogenInorganic forms, p. 643-698. In: Methods of soil analysis, Part 2. Chemical and microbiological properties. Agron. Monogr. 9. 2nd ed.

Roe, N.E., P.J. Stoffella, and H.H. Bryan. 1994. Growth and yields of bell pepper and winter squash grown with organic and living mulches. J. Amer. Soc. Hort. Sci. 119:1193-1199. 